\title{
Response to crisis
}

I am writing from California, which is now part of a new integrated world, all connected to the events and response.

It is quite clear we are living in an interconnected and often virtual world. The boundaries have disappeared. In the World Trade Center people from countries all over the world died, including the Middle East. We are involved here in California with friends of friends who died, with an office connected to the office on top of the building where more than 700 died, and they listened on an open line. There was the horror of people jumping from top floors.

Our anxiety is expressed in many ways: grounding aircraft, our care for those involved, anger, apathy, pain and perplexity. We sit glued to the television, numb, yet waiting for news. We expressed it in meetings at the university, where I led a two hour session with the School of Public Health. Fear of reprisals from scarf-clad women, voice of peace from Quakers and others, stories of friends and families, worries about the dust and health, and more. Grief is the primary fear. The closest diagnosis is post-traumatic stress disorder. Some of us are busy helping in this area. Others, in New York are mobilised.

As an information junkie, I have been observing responses. The official responses seem to move from immediate military action, to using all our toolseconomic, diplomatic, intelligence, coalitions and more. In the Administration the secretary of state, Colin Powell seems to hold the broadest stance. Listening to him, suggests an awareness that with a changed world, we need new kinds of responses. Fear forces us to respond as before.

A personal story is worth telling, in this regard. A war game was held in the 60 s where they acted out an invasion of India by the Chinese. A friend played the president of the United States. He decided to do what we call a "paradoxical intervention." $\mathrm{He}$ ordered dropping food, and radios, and withdrew troops. He encouraged discussion.
Peace resulted, and new patterns of relations occurred, and he achieved peace.

My friend asked me to the debriefing, proud of his success. At the beginning, a high military man turned to my friend, and said, "Mr X, you will never participate in war games again! You have not played by the rules!"

Sadly, it is all too easy to use old responses, and this is what we hear from many. We wonder if a new paradigm will emerge?

Most important, there are some important changes. Communities are organising. They are volunteering, and using people of multiple skills to deal with the problems. I am struck how fast they found the terrorists. Colin Powell reports that government operations have changes overnight, new security procedure, new corporate involvement, and changed view of the enemy.

The enemy is no longer a place or those people. It is a virtual army, operating from cells, and keeping in touch somehow. They are using all our technological skills and even tools. People recognise that the US have supported Bin Laden, Iraq, Iran, and others who turned against us. We have educated them in our schools, taught them military tactics, to fly. How to re-examine our policy, is critical.

Our concern for the health of people is critical. Violence is our problem. So, are disasters. The environmental pollution of smoke made up of asbestos, wallboard, steel, and glass is an immediate one. Grief is central to all-the survivors and their loved ones. Indeed grief work is what we all will be doing.

We are in the process of remaking ourselves. I do hope that we can do so.

16 September 2001
LEN DUHL

\section{Revenge is not the answer; leadership could be}

From a public health perspective. one of the major challenges after 11 September is whether we can build a more caring communitarian world. The signs are not good. Behind the media hype, what comes through is largely a lack of institutional caring. People as individuals still seem to care even if their voices are muted.

Markets and neoliberal globalisation serve to create yet greater maldistributions not only of resources but also of power and influence. They reduce us too often to being consumers only when being citizens, especially world citizens, is increasingly important. When leadership is missing from the world stage, there remains no one but world citizens to adopt a world perspective.

Television pictures and the fact that this was the US filled the vacuum created by the absence of world leadership, capturing world minds more than for example Rwanda ever did. Leaders of Mandela's stature are needed. Despite having suffered so much for so long, he established the Truth and Reconciliation Commission on the basis of sentiments such as: "You can't build a united nation [or a united world?] on the basis of revenge." In comparison Bush's antics look like those of a very small man.
The calls for revenge against terrorism echo those against opponents of last century's British imperialism in Africa. Yet so often former "terrorists" eventually sat down with representatives of the British government and successfully negotiated the independence of their countries.

The reopening of the US Stock Exchange was revealing. In advance, we heard that the "fundamentals" of the US economy remained strong. Fundamentalism was otherwise used in a pejorative sense about a major world religion. But maybe we are dealing here with two religions?

When the Stock Exchange did open, despite institutional voices calling for patriotism and for this great beast to act with compassion and commitment, there was a major initial fall and various falls since, and these despite almost certainly the US government pumping in billions of dollars. The major symbol of capitalism served up what it would be expected to serve up: greed and a lack of commitment to anything other than money making. It was not able to do otherwise even on the one day in the world's history when investors might have looked beyond the mighty dollar. We can now finally and assuredly reject 
the idea that there is anything or could be anything other than greed involved in capitalism. It lies exposed for what it is. The market has no heart. It does not-it cannot-care.

Whoever was responsible for the attacks should be brought to justice for these appalling crimes. While the inferno of racial and religious hatred that has followed is at least as appalling, other voices are beginning to be heard. The notion of the world being a village community has never been more explicit than on 11 September. Let the villagers use this to build bridges, mutuality, reciprocity, respect and love across national boundaries. The fact that the US is being forced back into the world community rather than seeing itself standing over it has to be a good thing. We villagers must develop institutions that more accurately reflect our world values but it would seem that nothing less than a major revision of modern capitalism is now needed to promote anew the health and happiness of the world community and especially those in developing countries. There remains the horrible feeling however, as the US prepares to wage war not to solve the problem of terrorism but to make themselves feel better by "doing something", that it is already too late.

Curtin University, Perth WA 6845, Australia
GAVIN MOONEY

\section{A new international public health target}

The tragedy of New York, Washington, and Pittsburgh is both immediate and long term. Immediate in its violent loss and bereavement; the anger, anguish and personal "what ifs" that will devastate psychological wellbeing over the next few weeks and months. What if she/he had missed the train, woke up late, been on a lower floor, not gone back to their desk, not taken that plane, had a few more seconds...? I breathed a huge sigh of relief at news that my brother and his family who live in NY city were all safe. Not so for so many others.

The longer term effects will be more subtle and harder to both express and manage. I am an American living abroad, was an early teenager during the Cuban missile crisis. In talking with my 13 year old son, I suddenly and very uncomfortably remembered what it felt like at 13 to be afraid of death. A death coming I knew not when nor where. It would come loudly and violently as a bomb. It might hurt, I might not be with family or friends and may not be able to say goodbye. I had recurrent nightmares, lived with anxiety although at 13 I could not name what I felt. And now, he is doing the same.

In Afghanistan people live daily with an equal loss, though arguably less sudden and violent. Their children and family members die each day from starvation and disease. Which is worse and more damaging to watch and experience? How could one answer such a question? Their life expectancy is well below that of America. They unfortunately live all too frequently with anxiety of loss and war. It is human to feel envy and hatred of those that have when you have not. In society people respond differently and so it is with the Middle Eastern societies where the perceived injustices have festered and grown and now spill over.

A public health consideration may need to step out of the comfort zone and challenge some of the prevailing national and party political issues. How do we encourage and develop good psychological health, particularly in our children and young people, if they live in fear and learn to respond to fear and anxiety with aggression? How do we also encourage good psychological health in nation states? The fear is different, American and English children fearful of their overall safety, anxious about war, loss, and death. Afghan children fearful of hunger, cold, repression, disease, and death. Causes of fear may differ; outcomes are all too often similar. Is this a public health issue? I believe it is.

Having lived through the Cuban missile crisis I then spent my later teenager and early adult years living with the Vietnam war. My brother was 15, not much older than my son is and the same age as my nephew, at the time Americans began to fight in Vietnam; and 23 when he died there. I watched a bit of my mother die with him; and, a bit of my other brothers and me changed irrevocably. I vowed never to experience that; no son of mine would be sacrificed to war.

Now I have a son and my fear and anxiety are high; so are his. So presumably are many peoples in many countries.

I am angry with whoever actively or passively authorised the USA assault. They (individually and collectively) need to be confronted with the results of their actions. I want to shake them, shout at them, rant and rave at them. And I also want to ask them what has happened in their lives that has caused them to hate so much, that has led them to commit this act. I want to ask myself, as an American and I want America however painful to ask what could we have done differently? How might this have been avoided? And then we all need to act. I hope, at the moment seemingly against hope, that the action will not be about blanket aggression. Is this selfishly motivated, a mother trying to look after her son, protect his future? Possibly. And my instinct tells me that I share this feeling with many Afghan, Palestinian, Israeli, Arab, American, and English mothers. A desire to grow physically and psychologically healthy children - to see them live in peace and well being. Surely this must be one of our most pressing international public health targets?

ANDREA CAMPBELL

Sefton Health Authority, Waterloo, Merseyside, UK;

Andrea.Campbell@sefton-ha.nhs.uk

24 September 2001 